\title{
Livelihood Pattern among Construction Laborers in Urban Sprawls: A Study of Jammu City
}

\author{
Ankush Gupta \\ Research Scholar, Department of Sociology, University of Jammu, Jammu and Kashmir, India \\ E-Mail: ankushg899@gmail.com
}

\begin{abstract}
This paper seeks to understand the livelihood pattern of construction laborers in Jammu city in the state of Jammu and Kashmir (J\&K). It has dealt with the life of the people living in urban sprawl who have migrated into the city from various parts of the country in search of livelihood. This paper has discussed the causes responsible for their migration and the problems they are faced with while living in the city. In the city of Jammu, various groups and communities, especially those who migrated from outside created their networks. They got influenced by the local socio-cultural and economic factors and at the same time impacted the society and economy in the settled areas. It was observed that their stay in Jammu is of longer duration still they feel alienated in the city.

Keywords: Urban Sprawl, Construction Laborers, Jammu City, Livelihood, Migration
\end{abstract}

\section{INTRODUCTION}

The City has remained a relevant category to be studied in Urban Sociology where the focus is on heterogeneity, impersonality, interdependence and the quality of life (Wirth, 1938). The word urban has been defined in the Oxford Dictionary as 'pertaining to town or city life' (Park, 1925). It is derived from the Latin word 'Urbs' a term used by the Romans for 'City.' The term 'Urban' refers to towns or cities having marked secondary and tertiary functions along with a municipality or notified area committee. An urban community may be defined as a group of people having a specific minimum population or numbers and also possessing specific specialized economic, political and social structures with some recognizable characteristics (Jayapalan, 2013).

The official definition of urban area in India includes - all places with a municipality, corporation, cantonment board or notified town area committee, etc. Similarly, all other places which satisfy the following criteria: i) A minimum population of 5,000; ii) At least 75 per cent of the male main working population engaged in non-agricultural pursuits; and iii) A density of population of at least 400 persons per sq. Km. (Census of India, 2011).

An Urban Agglomeration, consisting of adjoining outgrowths and at least a statutory town must have a minimum total population of not less than 20,000. In the state of Jammu and Kashmir, there are 7,935 towns in the country, 475 Urban Agglomerations and 981 out-growths (Census of India, 2011). As per the census 2011, the urban Urban population of India is 31.16 percent, while that of
Jammu and Kashmir (J\&K) state it is $27.38 \%$ (Jammu Development Authority, 2004).

Urban sprawl has been broadly defined as unplanned, uncontrolled and uncoordinated single-use development that does not grant an attractive and functional mix of uses. It is not functionally related to surrounding land uses and which variously appears as low-density ribbon or strip, scattered, leapfrog or isolated development. It may occur in the form of strip development, corridors of high accessibility along roads, uncoordinated scattered development or in the form of compact development. (Nelson and Duncan, 1995).

Urban sprawl or suburban sprawl describes the expansion of human populations away from central urban areas into previously remote and rural areas, often resulting in communities reliant upon heavy automobile usage. Urban sprawl is a multifaceted concept involving outward spreading of a city and its suburbs to exurbs, to low- density and often auto-dependent development on rural land. In simple terms, the uncontrolled spread of urban development into neighboring regions is known as 'Urban sprawl' (Lynch, 1954).

The term 'sprawl' is most often associated with land use in the English-speaking world; in Continental Europe, the term 'peri-urbanization' is often used to denote similar dynamics and phenomena. Urban sprawl over the decades has become the subject of analysis about how to manage urban growth. Discussions and debates about sprawl are often made unclear by the uncertainty of the meaning associated with the phrase.

For example, some commentators measure sprawl only with the average number of residential units per acre in a given area. However, others associate it with decentralization (spread of population without a well- defined center), discontinuity (leapfrog development, as defined below), segregation of uses, and so forth. In this study, the term 'Urban Sprawl' refers to the uncontrolled spread of population and infrastructure leading to the incorporation of fringe areas into the fold of the city (Flanagan, 2010).

The Urban Sprawls here includes those areas where the inhabitants are construction workers from different states like Madhya Pradesh, Chhattisgarh, Uttar Pradesh, and Rajasthan \&Haryana who have come to Jammu city to earn 
a better livelihood. They have added to the urban population of Jammu city which now stands at 5.02 lakh (Census, 2011).

\section{URBAN SPRAWLS}

The urban sprawls identified and selected for the study include the following

1. Narwal Sprawl

2. Belicharana Sprawl

\section{A. Narwal Sprawl}

Slums are areas of dilapidated houses which are in the state of disrepair and unfit to live in. In developing countries, this phenomenon is more common as compared to developed countries. The reasons responsible for growing slums are rapid rural-urban migration, high unemployment, poverty, poor planning, natural disasters, and social conflict. The slums in Narwal area are the result of immigration of people in Jammu region from states such as Madhya Pradesh, Uttar Pradesh, Jharkhand, and Chattisgarh. The migration is due to the result of push factors such as improper sources of income and livelihood. Most of these people have been living here for about 15 years. This slum is situated near stadium morh Channi Himmat and consists of households where all people have come from Rampura village in Chattarpur district of Madhya Pradesh.

They have been living there for almost 7- 8 years. In-depth interviews, non- participant observation and focused group discussions were used as tools for collecting data. Three families came initially, who informed further others about earning their livelihood and settling in Jammu City. Since the last 4 to 5 years their number has kept on increasing, and more and more families are coming.

According to informants of these slums, they are living on private land, and each family pays a monthly rent of rupees 400 to the owner for each hut. Every household pays rupees 200 for electricity, but meters have not been installed yet. Here push factors are in operation because their place of origin is unable to provide them the adequate source of livelihood; this compelled them to move into Jammu City. According to them, they get rupees 600 for skilled labor work and Rupees 400 for unskilled labor work which is comparatively better than the wages they used to get in Madhya Pradesh.

In Madhya Pradesh, the present rate is rupees 250 for unskilled labor work and 300 rupees for skilled labor work. Their skilled work includes brick and block laying, concrete finishing, polishing, tile setting, painting, marble fitting, pipe fitting. Therefore, they are known as the community of carpenters, electricians, masons, painters, plumbers, and welders. Some females also work with their husbands according to their will. However, mostly male members prefer their females to take care of their family and children.
Their children go to a school named government school Gujjar colony. They have a small shop in their locality to cater to the local needs which are run by a female member of the household.

\section{Household Structure}

Each household consists of husband, wife and their children and their unmarried brothers and sisters. Old members usually prefer to stay back in their original villages to take care of the homes there.

\section{Basic Facilities}

Almost every 3rd household has television for recreation. However, there is a problem of water shortage. They carry water from the tank which is half a kilometer away from the place of their residence. They keep earthen pots (Gada) to cool water. They have carved out spaces for bathing but go outside for latrines in open spaces. This open defecation can be harmful to them as well as for the surrounding.

\section{Employment Related Problems}

These people have come from their original place to earn their source of livelihood as they earn here better and their original place is unable to provide them sufficient source of livelihood. However, they are also faced with work-related problems in Jammu as they do not get work on an everyday basis especially unskilled worker.

\section{Daily Routine}

Their daily routine is like male and female members both get up early in the morning. After sending their children to schools, they assemble at Sunjwan chowk, Siddhra chowk or Narwal chowk. They wait there for $2-3$ hours till 10 am for agents so that they can be hired for work. If the agent hires them for work (labor) they earn their day's income, otherwise they come back in their huts and spend time by playing cards and other indoor games, etc. This is the case of unskilled laborers where they have to search daily for their work. However, once skilled laborers get their work, they are engaged for about 2 to 3 months their work is over, and then they search for other work. Their earning and living conditions are much better than unskilled laborers. Skilled laborers are usually engaged in the construction of showrooms, hospitals, significant buildings, construction of houses. They are so skilled that whatever pieces of marble and tile they are left with; they use that in the construction of their huts

\section{Educational Qualification}

A few of these people are illiterate while others are literate up to the level of 6th to 7 th standard only. However, now their children, both boys, and girls are getting an education in nearby government schools up to Matriculation standard. 


\section{Caste Structures}

All these people have scheduled castes which include castes like Pal, Verma, Brar, Anuragi, etc. On conducting interviews, it was found that they prefer to stay with the people of their caste not only in the place of origin but in the place of destination as well. They are highly conscious of their caste and follow its rule strictly.

\section{Food Habits}

They consume vegetarian and non- vegetarian kind of food. Therefore, they do not have ration cards and purchase ration from public shops. They all have Aadhar cards. They have saving deposits in their account.

\section{Celebration of Festivals}

They celebrate important festivals in Jammu which they used to celebrate in their place of origin like Shivratri, Dussehra, and Diwali Krishna Janmashtami. If possible, they prefer to celebrate the festivals in the places of their origin with their extended family members. However, if work does not permit them to go out in their places of origin, then they celebrate festivals with their family members here.

\section{Marriage}

Their marriages are endogamous. They marry within their caste and sub-caste as well. They celebrate marriages in their place of origin as they could invite all their relatives there.

\section{B. Belicharana Sprawl}

This sprawl consists of families of people who are migrants from Shakti village of Bilaspur district of Chattisgarh state \& Haryana. They have constructed their huts on government land. Reasons for their migration include unavailability of proper and regular source of income in their original place or emigration place. They are both skilled and unskilled labourers. They migrated in the year 1994 and initially lived near (Maheshpurachowk ) Bakshi Nagar for 7 years, but due to the construction of medical hospital (Super Speciality Medical Hospital ) they have shifted their residence in their present place according to the order of the then Governor of J\&K, Jagmohan. The land which is inhabited by them is government land and has been allotted to the Irrigation department. When interviews were conducted in this Sprawl it was found that officials of the irrigation department allowed them to raise their huts in return of monthly rent.

\section{House Structure and Basic Facilities}

They pay about 400 rupees to government officials of the irrigation department. Their huts are more significant as compared to huts in other sprawls. They have tap water facility for drinking and other purposes. They do not have electricity meters installed in them. Like other slum dwellers, they also defecate in open which can bring epidemics. So, like every slum it is also associated with a sanitation problem.

\section{Education Level}

The children go to nearby government schools. They also have primary schools and Angan wadi centers for the children. The workers include skilled and unskilled labourers. They work as hired labourers in the private sector for rupees 400 and sometimes get contractual work in the government sector for rupees 300 . In this sprawl, skilled and unskilled labourers are engaged in the construction of bridges, flyovers, in brick kilns and other construction works. In this sprawl, unlike other sprawls, women do not do work as hired labourers. Instead, some of the women work as maids in households in adjacent colonies and contribute to the livelihood of their households.

\section{Festivals}

Among festivals, Dushera which they dedicate to Goddess Dhanteshwari, Teeja, Lokotsav, Hareli Festivals are celebrated among them. If possible for them they would prefer to celebrate festivals with extended family members in their native places.

\section{Marriage}

They practice caste endogamy and prefer to marry in their native places.

\section{Caste}

These people belong to Scheduled Castes.

\section{CONCLUSION}

To conclude it can be said that various communities of people have come into Jammu City with different reasons. For instance, construction laborer's residing in different areas of the city from the last 17-18 years have come due to economic reasons due to insufficient means of livelihood in their places of origin. These people are from different states of India like Madhya Pradesh, Chattisgarh, Uttar Pradesh, Rajasthan and Haryana. They people reside in urban sprawls in areas like ChanniNarwal, Belicharana, Jammu Akhnoor (Muthi) and Ban Talab.

Construction workers who constitute a major workforce in Jammu region have moved in Jammu city due to economic reasons have their views. According to respondents Jammu and Kashmir is a militancy-affected state but because it was the question of their survival and livelihood that made them decides to come in the City.

In Jammu city, as the study has shown, they get much better wages from their places of origin. According to the construction laborer's, exceptionally skilled workers of 
Narwal sprawls, the whole group of laborers' have contributed as in the construction of Shopping malls such as wave mall, big bazaar and hospitals. Even houses and buildings of local people, so they play a significant role as a workforce in the city, and the city has an efficient and hardworking workforce.

Construction laborers are residing in Jammu city for the sake of livelihood and are very much attached to their native places. Even after living for years in Jammu, they feel somewhat alienated. They save money and make sure gifts and items for their near and dear ones. They prefer to go to their native places at the time of festivals and celebration of marriages. There is some feeling of alienation in them and are deeply attached to their native places.

\section{REFERENCES}

[1] Arthur C. Nelson, \& James B. Duncan. (1995). Growth Management Principles and Practices. Chicago: Planners Press. American Planning Association.

[2] Flanagan, \& William.G. (2010). Urban Sociology, Images and Structures. New Delhi: Chaman Enterprises.

[3] Jayapalan, N. (2013).Urban Sociology.New Delhi: Atlantic Publishers and Distributors.

[4] Lynch, Andrew. (1954). The Image of the City. England: The M.I.T Press.

[5] Park, \& Robert E. (1915). The City: Suggestions for the Investigations of the Human Behavior in the City. Chicago: University of Chicago Press.

[6] Wirth, \& Louis. (1938).Urbanism as a way of life. Chicago: American Journal of Sociology.

[7] Census of India 2011, Provisional Population Total, Series 2, Jammu and Kashmir.

[8] Jammu Development Authority (2004). Jammu Master Plan, 2021, Jammu: EssEss Offset Press. 